日消外会誌 $36(10): 1421 １ 425,2003$ 年

症例報告

\title{
回腸末端憩室炎による成人腸重積の 1例
}

\author{
医療法人川崎病院外科 \\ 島田 和典 中島 信一 伊藤 章 後藤 正宣
}

症例は 49 歳の男性 . 虫垂切除術の既往があり, 右下腹部痛にて当科受診した . 腹部単純 X 線検査上イレウスと診断し，入院の上，保存的治療を開始した . 右下腹部の鈍痛は持続し，イ レウス症状は緩解，増悪を繰り返した . 腹部エコー，CT 検査では上行結腸に渦巻き状構造を 認め, target sign 陽性であった .注腸造影では多結節状の腫瘤陰影を認めた . 大腸内視鏡検査 にて回腸結腸型腸重積症と判明したが, 先進部に腫瘍は認めず, 生検でも悪性所見はなかっ た .内視鏡下での整復は不可能であり，開腹術を施行した . 手術時には重積は解除されていた が回盲部に手拳大の腫瘤を認め,右半結腸切除術施行した.病理組織診断にて回腸末端に憩室 が多発しており，乥の周囲の慢性炎症および線維化が原因と考えられた .

\section{はじめに}

成人の腸重積は比較的まれな疾患であり，一般 に癌などの悪性疾患やポリープが原因となること が多く , 媳室に関連して発症することはまれであ る.今回我々は，回腸末端に憩室が多発し，これ らが原因で発症したきわめてまれな成人腸重積を 経験したので, 若干の文献的考察を加えて報告す る.

症例

患 者：49歳, 男性

主 訴 : 右下腹部痛

家族歴：特記すべき事項なし．

既往歴 : 20 年前に虫垂切除術

現病歴 : 1999年 6 月 3 日右下腹部痛が出現し， 同日当科受診し，精査目的に入院となった。

入院時現症：身長 $170 \mathrm{~cm}$,体重 $65 \mathrm{~kg}$ ，右下腹部 を中心に圧痛を認めたが ,Blumberg 徵候,筋性防 御などの腹膜刺激症状は認められなかった . 腹部 腫瘤を触知せず，腸雑音はやや方進していた .

入院時血液検査所見: CRP $5.4 \mathrm{mg} / \mathrm{dl}, W B C$ $8,300 / \mu \mathrm{l}$ と炎症所見を呈したが, 腫瘍マーカーは 正常であった .

腹部単純 X 線写真 : 小腸を中心にニボー像を

$<2003$ 年 4 月 30 日受理 $>$ 別刷請求先: 島田 和典 干 791-0281 愛媛県温泉郡重信町横河原 366 国立療 養所愛媛病院外科
Fig. 1 A bdominal X-ray film show ed dilated loops of small intestine and niveau.

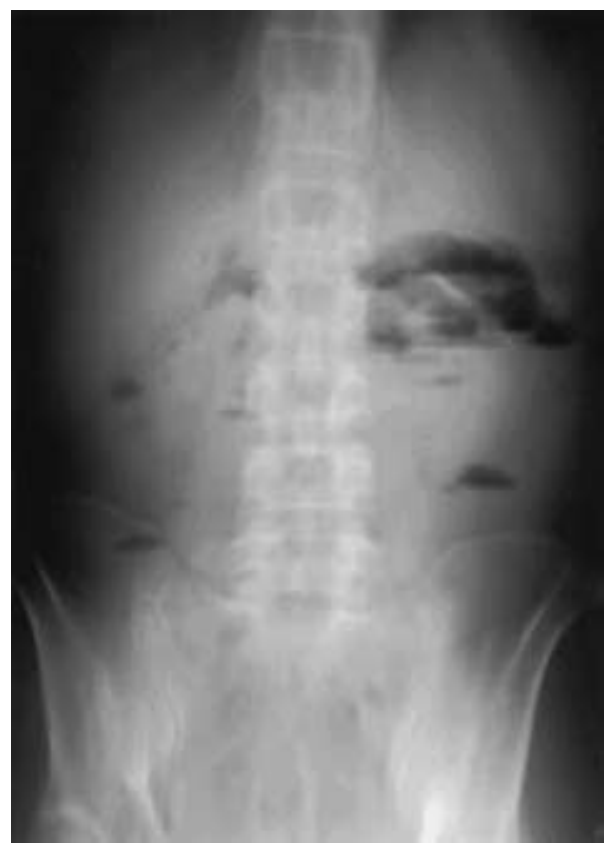

認め，イレウスと診断した (Fig.1) .

入院後経過 : 保存的治療を開始したが，右下腹 部の鈍痛は持続し，イレウス症状は緩解，増悪を 繰り返した。

腹部超音波検査 : 右下腹部に高エコー層と低エ 
Fig. 2 A bdominal ultrasonography showed multiple concentric ring sign of hy perechoic and hy poechoic lay ers in the right lower abdomen.

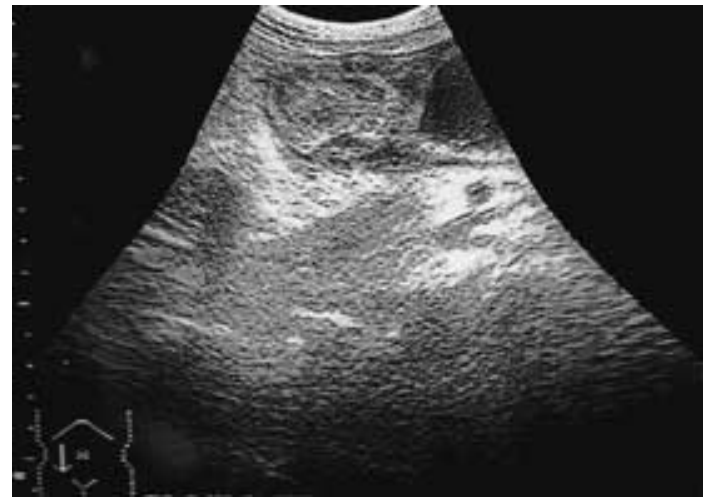

Fig. 3 A bdominal computed tomography showed target signs in the ascending colon (arrow).

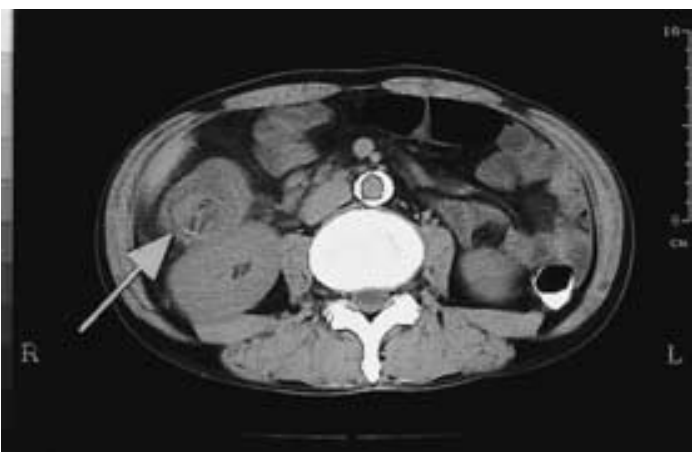

コー層の渦巻き状構造を認めた (Fig. 2) . 腹部 CT 検査 : 上行結腸に壁肥厚と high density と low density の層状構造を認め,target sign 陽性であった (Fig. 3) .

注腸造影検査：回盲部付近で多結節状の腫瘤陰 影像があり，造影剂の通過を認めなかった（Fig. 4) .

大腸内視鏡検査：上行結腸で口側腸管が肛門側 に重積しており，重積した腸管粘膜は発赤，腫脹 していたが, 腫瘍性病変を認めなかった . 同部の 生検では正常の小腸粘膜であり，悪性所見は得ら れず, 回腸結腸型腸重積症と診断した . 内視鏡下 での整復は不可能であった (Fig. 5) .
Fig. 4 Barium enema showed a multiple nodularfilling defect around the ileocecum.

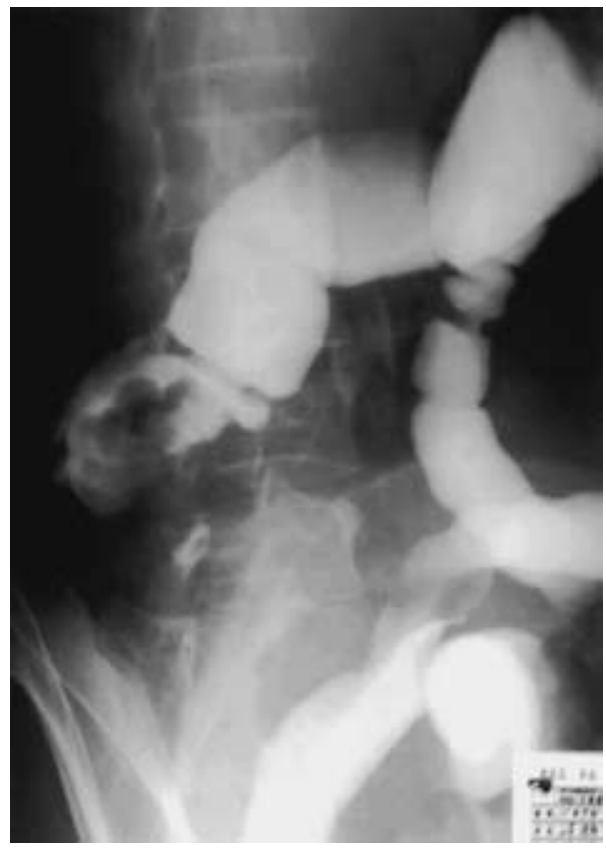

Fig. 5 Colonoscopy showed ileocolic intussusception and a tumor was not seen in the invaginated intestine.

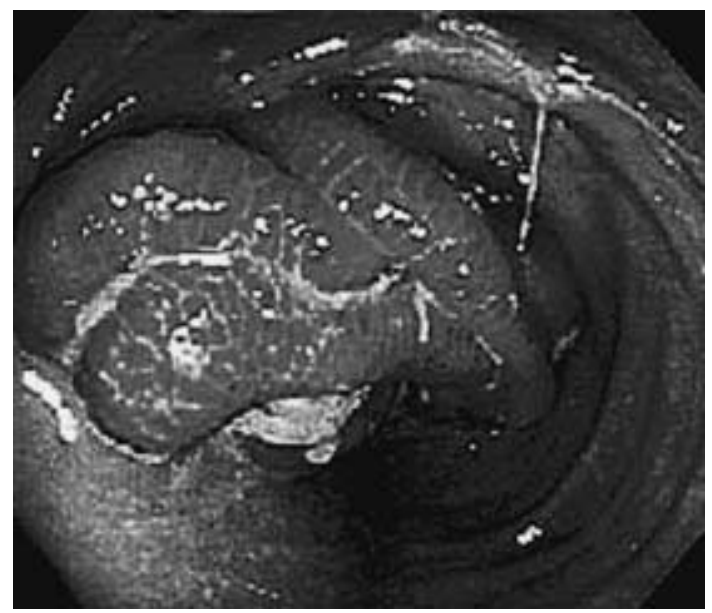

以上の所見より，回腸結腸型腸重積症の診断に て 1999 年 7 月 9 日開腹術を施行した .

手術所見：重積は解除されていたが，回盲部に 
Fig. 6 (A ) Macroscopic findings of the resected specimen show ed an ileocecal mass and the dilated ileocecal valve. Mucosal surface of the terminal ileum was irregular and $w$ all thickness $w$ as remarkable. (B) Schematic illustration of the resected specimen (arrow head : diverticula of the terminal ileum) (A ) (B)

A

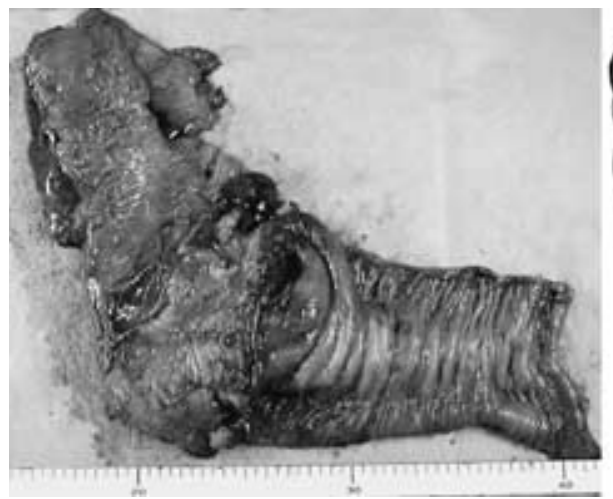

手拳大の弾性軟の腫瘤を認めた．回腸末端は通過 障害による拡張を認め，腸間膜のリンパ節は著明 に腫大し，悪性疾患を否定できなかった . 上行結 腸は短縮をきたしていたため，肛門側の surgical margin を考慮し, 結腸右半切除術を施行した .

切除標本：回腸末端の粘膜面は不整であり，著 明な壁肥厚と回盲弁の腫大を認めた（Fig. 6 A， B) .

病理組織 : 回腸末端に鄎室が多発しており, 光 の周囲の慢性炎症および線維化が腫瘤の原因と考 えられた . 賏室は筋層を欠いた仮性䕀室であった (Fig. 7) .また，摘出したリンパ節は炎症性変化の みであった . 以上の所見から回腸末端憩室炎によ る成人腸重積と診断した。

術後経過：縫合不全を認めたが保存的に治癒 し，術後 47 日目に軽快退院した .

\section{考察}

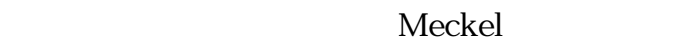
ばまれな疾患であり，剖検頻度は 0.006〜1.3\%で， 全消化管息室に占める割合は $2.7 \%$ 程度であ $ろ^{1)}$. 発生部位は上部空腸と回腸末端に多くみら れ，回腸憩室は空腸鄎室の約 $20 \%$ 程度である ${ }^{11}$. 半数以上が多発性であり,Williams は単発と多発 の割合を $1: 3$ と報告している ${ }^{2)}$.また，多くは筋
B

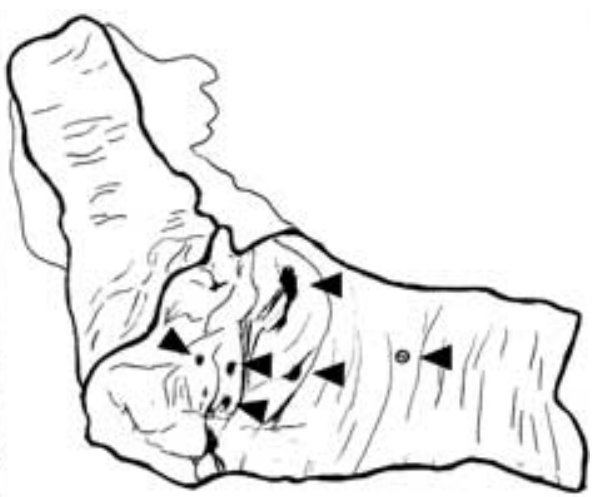

Fig. 7 Histological findings of the specimen showed multiple diverticulitis of the terminal ileum, pseudodiverticula lacking muscularis, surrounded by chronic inflammation and fibrosis .(HE stain, $\times 4$ )

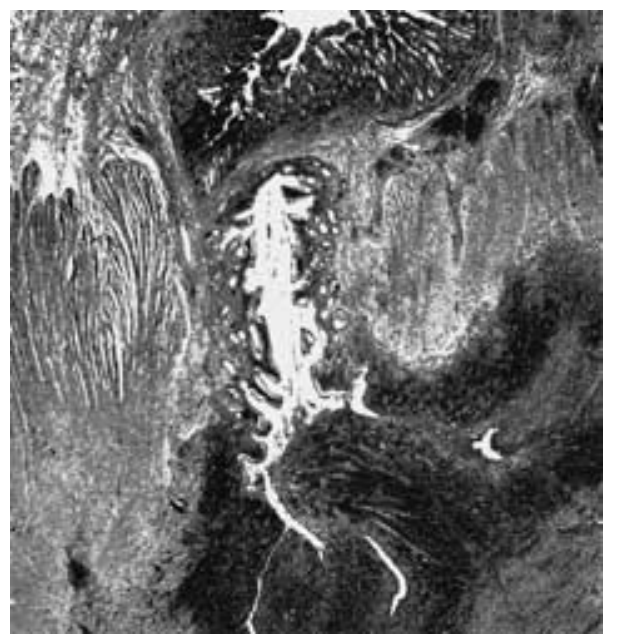

層を欠く仮性鄎室であり，腸間膜付着側に発生す $3^{11}$. 乥の理由として血管侵入部が抵抗減弱部と なり，腸管内圧の上昇により粘膜へルニアを生ず ると考えられている3. 無症状で経過することが 多いが, 10\% 程度に合併症を認め, 光のうち毠室 炎が最も多く，回腸息室炎では急性虫垂炎との鑑 
Table 1 Reported cases of adult intussusception due to non-Meckel's diverticulitis

\begin{tabular}{|c|c|c|c|c|c|c|c|}
\hline A uthors & Y ear & $\begin{array}{l}\text { A ge/ } \\
\text { Sex }\end{array}$ & $\begin{array}{c}\text { Chief } \\
\text { Complaint }\end{array}$ & $\begin{array}{l}\text { Clinical } \\
\text { Findings }\end{array}$ & Preoperative Diagnosis & Operation & Histology \\
\hline Kusano & 1999 & $51 / F$ & A bdominal pain & $\begin{array}{l}\text { Mass palpable } \\
\text { lleus }\end{array}$ & Intussusception & $?$ & $\begin{array}{l}\text { Diverticulitis of the } \\
\text { cecum }\end{array}$ \\
\hline Maeda & 1999 & $53 / \mathrm{M}$ & A bdominal pain & Mass palpable & $\begin{array}{l}\text { Intussusception due to } \\
\text { diverticulitis }\end{array}$ & $\begin{array}{l}\text { Ileocecal } \\
\text { resection }\end{array}$ & $\begin{array}{l}\text { Diverticulitis of the } \\
\text { cecum }\end{array}$ \\
\hline A sano & 2000 & $57 / \mathrm{M}$ & $\begin{array}{l}\text { Soft excrements } \\
\text { Leg edema }\end{array}$ & $?$ & $\begin{array}{l}\text { Intussusception due to } \\
\text { poly } p\end{array}$ & $\begin{array}{l}\text { Ileocecal } \\
\text { resection }\end{array}$ & $\begin{array}{l}\text { Diverticulitis of the } \\
\text { cecum }\end{array}$ \\
\hline Y amasaki & 2001 & $30 / \mathrm{M}$ & $\begin{array}{l}\text { A bdominal pain } \\
\text { Bloody excre- } \\
\text { ments }\end{array}$ & Mass palpable & Intussusception & $\begin{array}{l}\text { Ileocecal } \\
\text { resection }\end{array}$ & $\begin{array}{l}\text { Diverticulitis of the } \\
\text { cecum }\end{array}$ \\
\hline A be & 2002 & $57 / \mathrm{M}$ & A bdominal pain & T enderness & $\begin{array}{l}\text { Intussusception due to } \\
\text { Bauhin's tumor }\end{array}$ & $\begin{array}{l}\text { Ileocecal } \\
\text { resection }\end{array}$ & $\begin{array}{l}\text { Diverticulitis of the } \\
\text { cecum }\end{array}$ \\
\hline Maesawa & 2002 & $43 / \mathrm{M}$ & $\begin{array}{l}\text { A bdominal pain } \\
\text { F ever up }\end{array}$ & $\begin{array}{l}\text { Mass palpable } \\
\text { lleus }\end{array}$ & $\begin{array}{l}\text { Intussusception due to } \\
\text { the appendiceal tumor }\end{array}$ & $\begin{array}{l}\text { Ileocecal } \\
\text { resection }\end{array}$ & $\begin{array}{l}\text { Diverticulitis of the } \\
\text { cecum }\end{array}$ \\
\hline Our case & 2002 & 49/M & A bdominal pain & Ileus & Intussusception & $\begin{array}{l}\text { Right hemi- } \\
\text { colectomy }\end{array}$ & $\begin{array}{l}\text { Diverticulitis of the } \\
\text { terminal ileum }\end{array}$ \\
\hline
\end{tabular}

別に苦慮することがある .弚の他の合併症として， 出血, 腸閉塞, 穿孔, 腸内細菌増殖による消化吸 収障害，巨赤芽球性貧血などが報告されており， 特に穿孔や大量出血例では致死率が高く，緊急手 術が必要となる1).

Bokhari ら ${ }^{4}$ は回腸末端の惒室炎 28 例の合併症 として穿孔 21 例，消化管出血 3例，腸閉塞 1例， 回腸膀胱瘻 1 例, 空腸回腸瘻 1 例, 肺梗塞 1 例を 報告しているが，自験例のように腸重積を合併し た症例はなかった .

消化管憩室に関連した腸重積のうち非 Meckel 性の毠室炎に関連した腸重積の報告は極めてまれ であり，医学中央雑誌および関連文献より検索し えた限りでは自験例を含め 7 例のみであった (Table 1).すべて回盲部型の腸重積であり，回盲 部は腸間膜が長く，腸蠕動が盛んであるという解 剖学的特徵11)に起因するものと思われた . 病悩期 間については記載がないため不明であつたが，主 訴は腹痛が 6 例で, 臨床所見は圧痛を伴う腹部腫 瘤が4例，イレウスが3例であった . 術前に診断 可能であった症例は前田ら ${ }^{6}$ の1例のみであり， CRP $15.8 \mathrm{mg} / \mathrm{dl}$,W BC $9700 / \mu \mathrm{l}$ と著明な炎症所見 を呈していた . 自験例を除く6例はすべて盲腸媳 室炎による腸重積であり，回腸末端の息室炎によ る報告は自験例が初めてであった . 自験例では䕀 室の慢性炎症によって回盲部の線維化や回盲弁の
腫大がおこり，また炎症に伴い回腸末端の漿膜側 が短縮され，粘膜側が相対的に伸展したことが腸 重積の原因と推測された . 炎症を伴う回盲部付近 の腸重積症例では腫瘍性病変が認められない場 合, 憩室炎を念頭において検索する必要があると 考えられた 。

本論文の要旨は第 55 回日本消化器外科学会総会 (2000 年 7 月 20 日, 宮崎) にて発表した。

$$
\text { 文献 }
$$

1) 福田能啓, 田村和民, 平川博之ほか：小腸款室 . 臨消内科 3:697-705, 1988

2) Williams RA : Surgical problem of diverticula of the small intestine. Surg Gynecol Obstet 152 : 621-626, 1981

3) Edwards HC : Diverticulosis of the small intestine. A nn Surg 103 : 230, 1936

4) Bokhari SR, Resnik A M, Nemir P Jr : Diverticulitis of the terminal ileum : report of a case and review of the literature. Dis Colon Rectum 25 : 660-663, 1982

5) 草野昌男, 友利美絵, 新 浩一ほか : 粘膜下腫瘍 樣の隆起を呈し腸重積を来した大腸鄎室の1例 . Prog Dig Endosc 55 : 66, 1999

6) 前田敏樹, 中野正人, 内田靖之ほか：回盲部㮩室 炎が関連したと思われる成人腸重積の1例，神戶 市中央区医師会編 . 学術集談会抄録. 神戶市中央 区医師会保険学術委員会, 神戶，1999, p28

7) 浅野寿利, 户田 央, 大場宗德ほか：腸重積樣の 症状を呈した大腸㮩室炎の1例.日臨外会誌 $61: 2817,2000$ 
8) 山崎智己, 根本雄治, 町田彰男ほか : 大腸鄎室炎 による成人腸重積の1例．日臨外会誌 $62: 416$, 2001

9) 安部幸一, 広沢光昭, 荒井雄樹ほか：内視鏡で診 断が困難であった腸重積の1例.Prog Dig Endosc $61: 64,2002$
10）前澤 寧，吉澤 繁, 佐田美和ほか : 腸重積との 鑑別を要した大腸熄室炎の1例 .Prog Dig Endosc $61: 65,2002$

11) 飯田辰美, 渡辺 敬, 大貫義則ほか：大腸癌と腸 重積症 . 日臨外医会誌 $49: 547-554,1988$

A Case of Intussusception in an A dult due to Diverticulitis of the T er minal Ileum

Kazunori Shimada, Nobukazu Nakashima, A kira Ito and M asanobu Goto

Department of Surgery, Kaw asaki Hospital

A 49-y ear-old man, who had previously undergone an appendectomy, was seen at our hospital because of a right lower abdominal pain. A diagnosis of ileus was made based on the results of an abdominal X-ray, and the patient underwent conservative therapy upon admission. A dull pain persisted in the right lower abdomen, and the ileus sy mptoms show ed repeated remission and relapse. A bdominal ultrasonography and computed tomography (CT ) examinations revealed target signs in the ascending colon. A barium enema showed a multiple nodular-filling defect. A colonoscopy revealed ileocolic intussusception. A primary tumor was not seen, and the biopsy showed no signs of malignancy. Since the intussusception could not be reduced by colonoscopic restoration, a laparotomy was performed under a diagnosis of ileocolic intussusception. A t the time of surgery, an intussusception was not seen but an ileocecal mass the size of a fist was found. A right hemicolectomy was performed. Histological findings of the specimen revealed multiple diverticulitis of the terminal ileum. T her efore, we believed that the mass was caused by chronic inflammation of the diverticula and surrounding fibrosis.

Key words : intussusception, diverticulitis of the ter minal ileum, adult

[Jpn J Gastroenterol Surg 36 : 1421-1425, 2003]

Reprint requests : Kazunori Shimada Department of Surgery, Ehime National Hospital 366 Y okogaw ar a, Shigenobu-machi, Onsen-gun, Ehime, 791-0281 JA PA N 